\title{
Cirugía ortognática y rinoplastia en el síndrome de Binder
}

Orthognathic surgery and rhinoplasty in Binder syndrome

\author{
M. Tito, C. Piero
}

Resumen: El síndrome de Binder es una patología caracterizada por hipoplasia nariz-maxilar, ángulo naso-frontal plano, senos frontales hipoplasicos, ausencia de la espina nasal anterior, columela corta y ángulo nasolabial agudo. El tratamiento del los pacientes con síndome de Binder puede ser ortodóntico o quirúrgico según la gravedad de la malformación. En este trabajo hemos realizado una revision bibliográfica sobre la etiología, el diagnóstico diferential y el tratamiento de la sindrome de Binder y presentamos un caso clínico de un paciente binderiano sometido a intervención de cirugía ortognática y rinoplastia con injerto de cartílago costal para recostruir el dorso y la punta nasal.

Palabras clave: Displasia maxilo-nasal; Síndrome de Binder; Injerto de cartílago costal.

Recibido: 27.12 .05

Aceptado: 06.10 .06

\begin{abstract}
Binder syndrome is a disorder characterized by nasomaxillary hypoplasia that results in a short nose, a frontonasal angle of almost 180 degrees, hypoplasia of the frontal sinuses, an absent anterior nasal spine, a short columella and an acute nasolabial angle. The patient can be treated orthodontically or surgically depending on the seriousness of the malformation. We review the literature on the etiology, differential diagnosis and treatment of Binder syndrome. We present the case of a boy with this syndrome surgically treated with orthognatic surgery and rhinoplasty with an L-shaped rib cartilage graft.
\end{abstract}

Key words: Maxillonasal dysplasia; Binder syndrome; Rib cartilage graft. 


\section{Introducción}

El síndrome de Binder es una patología congénita caracterizada por un fallido desarrollo de la premaxila. Binder, ${ }^{1}$ en 1962 describió a tres niños con las siguientes características: hipoplasia narizmaxilar, labio superior convexo, nariz vertical, ángulo naso-frontal plano, ausencia de la espina nasal anterior, atrofia de la mucosa nasal y senos frontales hipoplásicos. Antes del 1962, los pocos casos descritos de esta malformación fueron identificados en las publicaciones científicas con otras denominaciones como "facies scafoidea", "cara plana" o síndrome de la nariz plana congénita. Noyes, ${ }^{2}$ describió antes de Binder el aspecto clínico de la displasia maxilo-nasal, pero no la reconoció como un síndrome. La primera descripción de displasia maxilo-nasales remonta al 1882 cuando Zuckerkandl, ${ }^{3}$ describió una anomalía en el suelo de la fosa nasal en que la normal cresta que separa el suelo nasal de la superficie anterior del hueso maxilar estaba ausente. En su lugar había una pequeña depresión, la fosa prenasalis que constituía el margen inferior del vestibulo nasal. ${ }^{4}$ Recientemente, a Quarai, en New México, ha sido hallado un esqueleto prehistórico de un sujeto femenino amerindio de edad de 16-17 años cuyas características dismorfogenéticas aparecen típicas del síndrome de Binder. ${ }^{5}$ Aunque este síndrome sea poco frecuente, han sido publicados estudios con un número relativamente alto de pacientes por Delaire y cols. ${ }^{6}$ (37 pacientes), Olow-Nordenram y Radberg, ${ }^{7}$ (43 pacientes), Jackson y cols. ${ }^{8}$ (26 pacientes), Horswell y cols. ${ }^{9}$ (19 pacientes). El síndrome de Binder presenta una severidad diferente en los diferentes pacientes. Dependiendo de la severidad de tal síndrome puede en ciertos casos ser suficiente solo la terapia ortodóntica, mientras en los casos más graves se hace necesario un tratamiento combinado ortodóntico-quirúrgico multiescalonado orientado a la corrección de la deformidad de la pirámide nasal y al restablecimiento de unas correctas relaciones dento-esqueléticas maxilo-mandibulares.

\section{Caso clínico}

El paciente D.G. llegaba a nuestra consulta a la edad de 14 años. Los padres en su historia clínica de la primera infancia notaron aplastamiento de la pirámide nasal del niño asociado a la manifestación de malocclusion de clase III de Angle. Fue iniciada por lo tanto una terapia ortodóntica de expansión palatal y vestibuloversion del grupo incisivo superior intentando compensar la clase III, con escasos resultados estético-funcionales. Llegado a nuestra observación el paciente, en visión frontal, lateral y axial, presentaba una alteración de la euritmia de la cara caracterizada por: frente alta y aplastada con ángulo naso-frontal de aproximadamente $180^{\circ}$; aplastamiento de la pirámide nasal con ligera giba dorsal, acentuación de los surcos naso-genienos, retracción columelar con un ángulo nasolabial agudo, narinas de forma semilunar y protrusión mandibular junto a retrusión del maxilar superior (Fig. 1A). En el examen intraoral se detectaba una grave maloclusión de clase III dento-esquelética con overjet de $3 \mathrm{~mm}$, open bite en los sectores látero-posteriores, cross bite bilateral, linguo-inclinación de todos los elementos dentarios de la arcada inferior y contracción del maxilar superior

\section{Introduction}

Binder syndrome is a congenital pathology characterized by a failure in the development of the premaxilla. ${ }^{1}$ In 1962, Binder described three children with the following characteristics: maxillonasal hypoplasia, convex upper lip, vertical nose, flat nasofrontal angle, absence of an anterior nasal spine, atrophy of the nasal mucosa, and hypoplasia of the frontal sinuses. Before 1962, the few cases described of this malformation were identified in scientific publications with other names such as "facies scaphoidea", "flat face" or "congenitally flat nose syndrome"

Noyes ${ }^{2}$ described the clinical features of maxillonasal dysplasia before Binder, but he did not recognize it as a syndrome. The first description of maxillonasal dysplasia goes back to 1882 when Zuckerkand/3 described an anomaly of the nasal fossa floor in which the normal crest that separates the nasal floor from the anterior surface of the maxillary bone was absent. In its place there was a small depression, a prenasal fossa in the lower margin of the nasal vestibule. ${ }^{4}$ Recently in Quarai, New Mexico, a prehistoric skeleton of an Amerindian female aged 16-17 was found with typical dysmorphogenetic characteristics of Binder syndrome. ${ }^{5}$ Although this syndrome is uncommon, studies have been published with a relatively high number of patients by Delaire et al. ${ }^{6}$ (37 patients), Olow-Nordenram and Radberg ${ }^{7}$ (43 patients), Jackson et al.8 (26 patients), Horswell et al. ${ }^{9}$ (19 patients). Binder syndrome has a different degree of severity in different patients. In certain cases orthodontic therapy will be sufficient while, in the more serious cases, combined orthodontic-surgical multi-step treatment will be necessary. This is orientated towards the correction of the deformity of the nasal pyramid and the re-establishment of a correct dentoskeletal maxillo-mandibular relationship.

\section{Case report}

The patient $D G$, was presented at the age of 14 . His parents went back to the beginning of his medical history when, during his infancy, they had observed his flattened nasal pyramid in conjunction with Angle class III malocclusion. Orthodontic therapy was then started with palatal expansion and vestiboloversion of the upper incisors in an attempt at compensation of the class III malocclusion, with little aestheticfunctional results. Once under our observation, the patient's frontal, side and axial views showed eurhythmia of the face that was characterized by: a flattened, high forehead with a nasofrontal angle of approximately $180^{\circ}$, a flattened nasal pyramid and a slight dorsal hump, accentuation of the nasolabial fold, retraction of the columella with an acute nasolabial angle, crescent-shaped nostrils, mandibular protrusion together with retrusion of the upper jaw (Fig. 1A). In the objective endoral examination, a severe class III malocclusion of the dentoskeleton was detected with a $3 \mathrm{~mm}$ over- 
(Fig. 1B). En el examen cefalométrico de Ricketts se evidenció la ausencia de la espina nasal anterior, la reducción de la base craneal anterior $(\mathrm{SN}=73 \mathrm{~mm})$, notable reducción del ángulo de profundidad maxilar $\left(\mathrm{NA} \wedge \mathrm{FH}=82^{\circ}\right)$, con ángulo de profundidad mandibular aumentado $\left(\mathrm{NB}^{\wedge} \mathrm{FH}=87^{\circ}\right)$ (Fig. 2). Los radiogramas del raquis cervical excluyeron malformaciones de tal segmento esquelético. Sobre la base del examen clínico y del aspecto radiográfico, se puso diagnóstico de síndrome de Binder y se puso indicación de un tratamiento ortodóntico prequirúrgico. A la edad de 18 años el paciente fue sometido a intervención quirúrgica de osteotomía de Le Fort I del maxilar superior de elevación simétrica anterior de $1 \mathrm{~mm}$ y posterior de $3 \mathrm{~mm}$, adelanto de 3 $\mathrm{mm}$, osteotomía sagital bilateral de la mandíbula de Obwegeser-Dal Pont y su reposicionamiento en oclusión con el maxilar superior. Un año después de tal intervención se decidió efectuar una intervención de rinoplastia, consistente en alargamiento de la columela a través de plastia v-y e injerto de cartílago costal para reconstruir el dorso nasal y la espina nasal anterior (Fig. 3). El seguimiento de la última intervención es de 13 meses y los resultados estéticos y funcionales son excelentes (Fig. 4).

\section{Discusión}

El diagnóstico del síndrome de Binder es clínico y radiológico. Las características clínicas más importantes del síndrome conciernen la pirámide nasal y la oclusión dentaria. La nariz del binderiano presenta una punta aplastada y cayente a causa del defecto esquelético premaxilar y de las reducidas dimensiones horizontales del tabique nasal, las narinas aparecen de forma triangular, la columela es corta y el ángulo naso-labial es agudo. A causa de la contracción del maxilar superior debida a la atrofia premaxilar, las relaciones dento-esqueléticas resultan siempre de III clase. En los casos más serios la reducción del diámetro de las cavidades nasales en correspondencia de las narinas, en asociación a la contracción del maxilar superior, puede ser causa de distress respiratorio neonatal. Radiológicamente y en la análisis cefalométrica, ${ }^{9}$ se puede observar a veces retrusión de la glabela, hipoplasia de los senos fron-
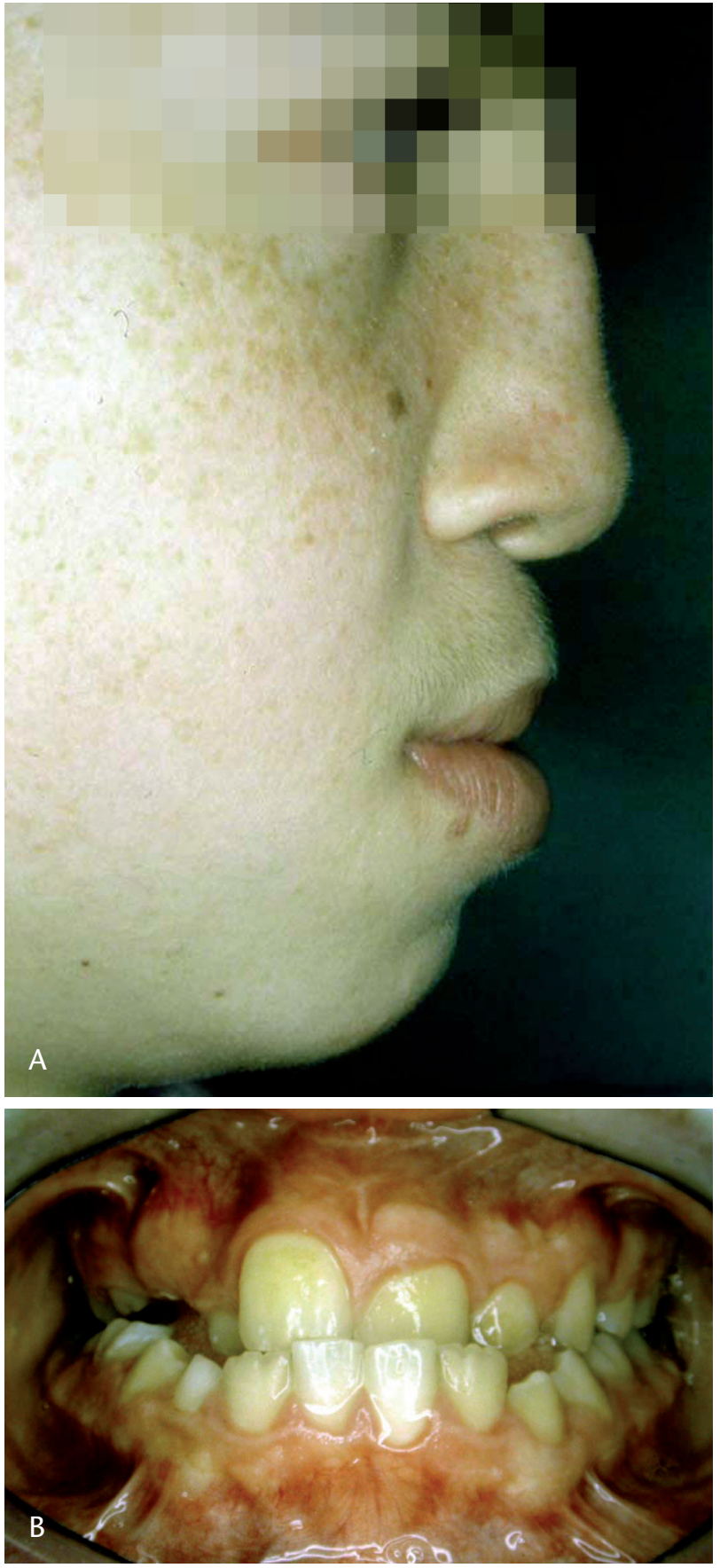

Figura 1. Paciente (A) y su oclusión (B) antes del tratamiento ortodóntico-quirúrgico.

Figure 1. Patient with (A) his occlusion (B) before orthodontic-surgical treatment. jet, open bite in the posterolateral sections, bilateral crossbite, lingual inclination of all dental elements of the lower dental arch and contraction of the upper jaw (Fig. 1B). Ricketts cephalometric analysis showed the absence of the anterior nasal spine, reduction of the anterior cranial base ( $\mathrm{SN}=73 \mathrm{~mm}$ ), considerable reduction in the maxillary depth angle $\left(N A^{\wedge} F H=82^{\circ}\right)$, with increased mandibular depth $\left(N B^{\wedge} F H=87^{\circ}\right)$, (Fig. 2). The radiograms of the cervical spine excluded any malformation of this segment of the skeleton. Based on clinical examination and radiographic findings, the diagnosis of Binder syndrome was made and presurgical orthodontic treatment was indicated. At the age of 18 the patient underwent surgery, which consisted in a Le Fort I osteotomy of the upper jaw with symmetric anterior lifting of $1 \mathrm{~mm}$ and posterior lifting of $3 \mathrm{~mm}$ and advancement of $3 \mathrm{~mm}$. A bilateral sagittal osteotomy of the mandible was performed, Obwegeser-Dal Pont technique, which was repositioned in occlusion with the upper jaw. A year after this intervention rhinoplasty surgery was carried out, which consisted in lengthening the columella through $v$-y plasty and rib cartilage grafting in order to reconstruct the nasal dorsum and the anterior nasal spine (Fig. 3). The follow-up after the final intervention was at 13 months and the aesthetic and functional results were excellent (Fig. 4).

\section{Discussion}

The diagnosis of Binder syndrome is by clinical and radiological examination. The most important clinical characteristics of the syndrome concern the nasal pyramid and den- 
tales, disminución de la longitud de la base craneal anterior, reducción de las dimensiones horizontales del maxilar, ángulo naso-frontal obtuso y atrofia de la premaxila junto al signo que, cuando se halla, es patognomonico del síndrome de Binder: la ausencia de la espina nasal anterior. No todos los autores creen que es necesaria la ausencia radiológicamente demostrada de la espina nasal anterior para llega al diagnóstico de síndrome de Binder; según Holmstrom, autor de un estudio, ${ }^{4}$ que a describe la precisa anatomía de la región nasal en pacientes binderianos, característica patognomónica del síndrome de Binder sería la pequeña cavidad a nivel de la porción más anterior del vestibulo nasal que corresponde a la "fossa prenasalis" de Zuckerkandl. En tal estudio Holmstrom localizó esta característica en todos sus pacientes (50), mientras la espina nasal anterior a menudo fue hipoplásica, pero a veces de normales proporciones. Sí pues es fácil reconocer a un paciente con síndrome de Binder típico, depende en cambio a menudo de la sensibilidad individual del especialista reconocer tal síndrome en un paciente en que el fenotipo clínico y las imágenes radiográficas no sean de unívoca interpretación. Hay además la necesidad de distinguir el síndrome de Binder de otros síndromes o condiciones patológicas que presentan con la primera características comunes. El diagnóstico diferencial debe hacerse con la acrodisostosis, las embriopatias producidas por Warfarin, el S. de Stickler, el S. de Robinow, el S. de Marshall, el S. alcohólico fetal y sobre todo la Condrodisplasia Punctata. ${ }^{10}$ La acrodisostosis se distingue del S. de Binder porque, además de la hipoplasia del tercio medio de la cara, resulta asociada a braquidactilia de los dedos de las manos y los pies. Anomalías esqueléticas distintivas del S. de Stickler comprenden palatosquisis y artropatía. La Condrodisplasia Punctata es la condición patológica con la cual más difícilmente se hace el diagnóstico diferencial del S. de Binder porque presenta la misma forma de la nariz típica del S. de Binder; sin embargo se puede diferenciar por las calcificaciones a nivel de las epífisis, de las malformaciones a nivel palatal y dental anterior y por el hecho que los niños con Condrodisplasia Punctata a menudo presentan problemas perinatales. ${ }^{10}$ Estas características, sin embargo, tienden a desaparecer con el crecimiento y éste es el motivo por el que resulta a veces imposible en un adulto el diagnóstico diferencial entre los dos síndromes. Por la misma razón unos autores creen que el S. de tal occlusion. The individual with Binder syndrome has a flattened, depressed tip because of the skeletal defect of the premaxilla and because of the reduced horizontal dimensions of the nasal septum. The nostrils appear triangular, the columella is short and the nasolabial angle is acute. As a result of the contraction of the upper jaw due to atrophy involving the premaxilla, the skeletodental relationship always results in class III occlusion. In the more serious cases, the reduction in the diameter of the nasal cavity in relationship with the nostrils, as a result of contraction of the upper jaw, can cause neonatal respiratory distress. Radiologically and in the cephalometric analysis (9) retraction of the glabella can be observed, together with hypoplasia of the frontal sinuses, a shortened anterior skull base, a reduction of the horizontal dimensions of the jaw, an obtuse nasofrontal angle and atrophy of the premaxilla. There is in addition a sign which, if found, is pathognomonic of Binder syndrome: the absence of the anterior nasal spine.

Not all authors believe that a radiologically demonstrated absence of the anterior nasal spine is necessary for a diagnosis of Binder syndrome. According to Holmstrom, author of a study that was aimed at describing precisely the anatomy of the nasal region of Binder patients, the characteristic pathognomonic feature of Binder syndrome would be the small cavity by the most anterior portion of the nasal vestibule that corresponds with Zuckerkandl's "fossa prenasalis". In his study Holmstrom located this feature in all his patients (50). The anterior nasal spine was often hypoplastic, but sometimes it had normal proportions. While recognizing a typical Binder syndrome patient is therefore easy, if the clinical phenotype and radiographic images of the patient are ambiguous, the individual sensitivity of the specialist will have to be exercised. 
Binder y la Condrodisplasia Punctata representen los extremos de un más amplio espectro de condrodisplasias. ${ }^{11}$ Las analogías con la embriopatía producida por Warfarin y con el S. alcohólico fetal ha hecho pensar en un origen común de estas enfermedades. En todas estas síndromes, en efecto, tal como en el empleo de fenitoína durante el embarazo, se establece un déficit intrauterino de Vit. K. ${ }^{12,13}$ Muchos autores han puesto atención a las similitudes de las anomalías faciales y esqueléticas inducidas por las embriopatías producidas por Warfarin y las producidas por fenitoína. Estas similitudes sugieren que las anomalías sean debidas a una deficiencia común de Vit $\mathrm{K}$ en el feto. Estudios experimentales sobre ratas han demostrado que la hipoplasia maxilo-nasal inducida por el Warfarin resulta asociada a una anormalidad del tabique nasal, que aparece menos desarrollado y menos calcificado de la norma. En el interior del cartílago ha sido hallada una proteína dependiente por la vitamina K, la matrix GLA protein. Aunque la función precisa de esta proteína no sea bien conocida, su presencia en el cartílago en crecimiento sugiere que su función normal sea prevenir la calcificación. En los fetos que tienen un déficit de Vit. K, la matriz GLA protein debería estar presente en forma inactiva y por lo tanto no lograría prevenir la calcificación incontrolada. En el S. de Binder la calcificación ectópica de la sutura entre vómer y premaxila, entre la sexta y la duodécima semana de vida embrionaria, podría ser responsable de la hipoplasia maxilo-nasal. Sin embargo, la hipótesis de Howe, ${ }^{12,13}$ no es aplicable a todos los sujetos con S. de Binder, porque no todos han experimentado un déficit prenatal de Vit. K, pero ayuda a aclarar la etiopatogenésis del S. de Binder, que resulta todavía muy confusa. Varias teorías patogenéticas han sido formuladas por muchos autores. Binder, ${ }^{1}$ creyó que el síndrome que lleva su nombre derivaba de una fallida inducción del prosencéfalo sobre el crecimiento de la premaxila. Resche y cols. ${ }^{14}$ sugirieron que la noxa patógena responsable del $\mathrm{S}$. de Binder tenía que actuar al mismo tiempo del desarrollo de las vértebras cervicales, puesto que malformaciones de estas últimas están presentes en más del $50 \%$ de los casos de S. de Binder. Converse y cols. ${ }^{15}$ creyeron que la reducción del crecimiento de la premaxila estaba causada por una alteración de la estructura cartilaginosa, mientras Noyes, ${ }^{2}$ pensó que la causa del síndrome era un trauma durante el parto. Así pues es muy debatida nática y de la rinoplastia. and rhinoplasty.

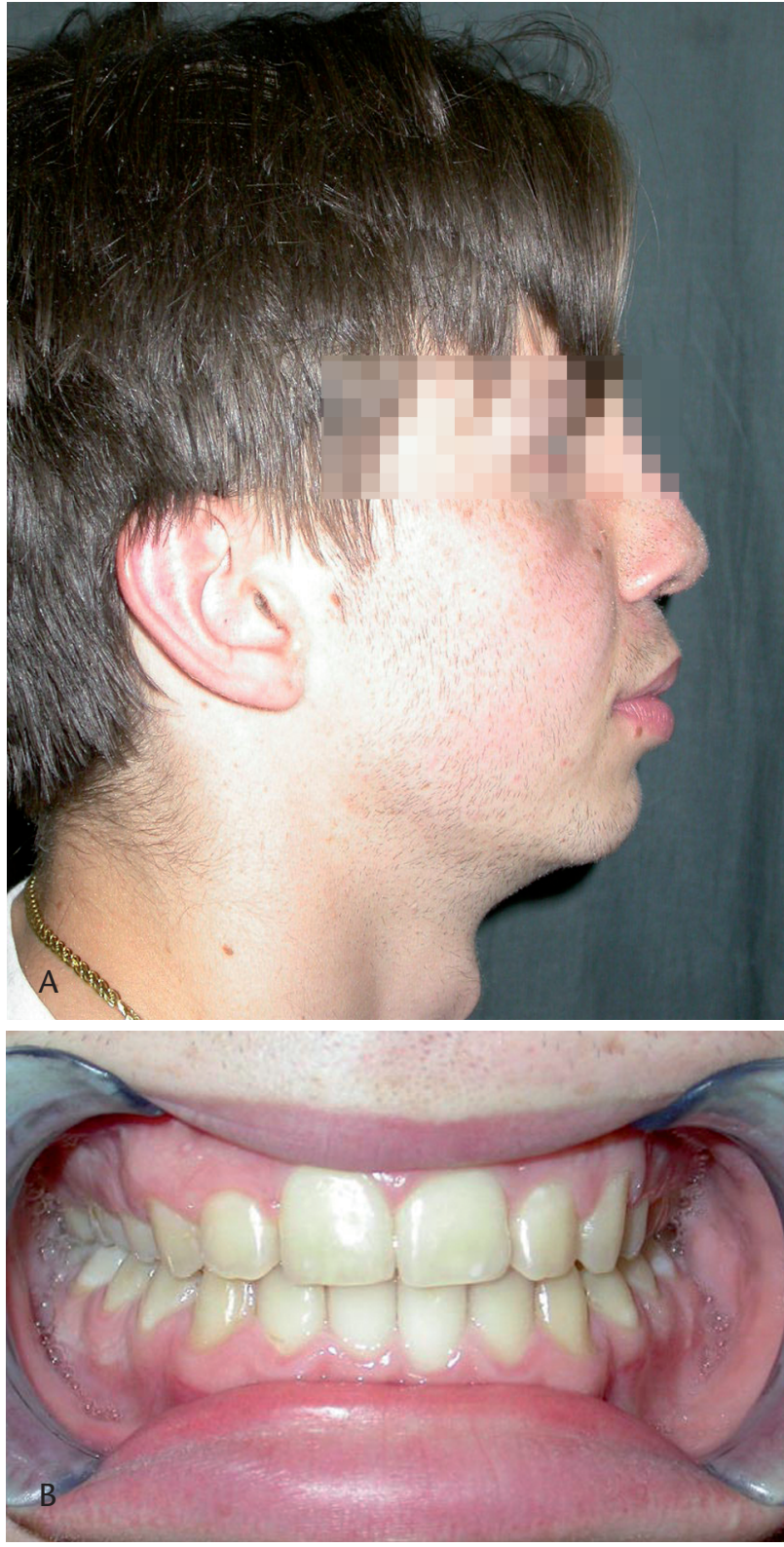

Figura 4. Paciente $(\AA ̊)$ y su oclusión (B) después de la cirugía ortog-

Figure 4. Patient (A) with occlusion (B) after orthognathic surgery Chondrodysplasia Punctata represent the extremes of a more ample spectrum of chondrodysplasias. ${ }^{11}$ The analogies with warfarin embryopathy and with fetal alcohol syndrome have led to a belief that these diseases have a common origin. In all these syndromes there is an intrauterine deficit of Vitamin K, as with the use of phenytoin during pregnancy. ${ }^{12,13}$

Many authors have given attention to the similarities between the facial and skeletal anomalies induced by warfarin embryopathies and those produced by phenytoin. The similarities suggest that these anomalies are due to a common vitamin $K$ deficiency in the fetus. Experimental studies on rats have demonstrated that warfarin-induced maxillonasal hypoplasia is linked 
la etiopatogenésis y la misma definición del síndrome de Binder, todavía menor acuerdo está presente en la literatura por lo que concierne a la terapia. Probablemente esto dependa de la rareza del síndrome, que no permite realizar estudios con un número de casos suficiente mediante una comparación de los tratamientos que se base en una sólida estadística. Resulta de todas formas evidente que el paciente binderiano debe ser tratado específicamente según la edad y la gravedad de su patología. En efecto, junto a pacientes que manifiestan relación molar de clase III de Angle y nariz moderadamente aplastada, podemos encontrar sujetos en clase III avanzada, con open bite anterior, ángulo naso-frontal de $180^{\circ}$, con patologías asociadas al raquis cervical y síndromes de deficit mental. La ortodoncia tiene un papel primario en los casos más leves, tal como en aquellos más graves, pudiendo, en los primeros, ser a veces suficiente para restablecer una estética y una función estomatognática aceptables. Los objetivos de la ortodoncia son: 1) antagonizar o corregir la contracción del maxilar superior; 2) conseguir un ajuste oclusal; 3) estimular el desarrollo sagital del hueso maxilar (máscara de Delaire); 4) preparar el paciente a la intervención de cirugía ortognática, cuando ésta sea necesaria. Runas y cols. ${ }^{16}$ en un estudio radiológico conducido sobre un niño de 11 años, sustentaron que la máscara de Delaire consiguió un menor efecto de adelanto del maxilar en un sujeto binderiano con respecto al sujeto no afecto por este síndrome, a causa, según los autores de la reducida capacidad de crecimiento de las suturas circumaxilares; además, cuando es removida la máscara de Delaire la recidiva es casi completa. En los casos más graves es necesario recurrir a la terapia quirúrgica. Los objetivos de la cirugía son: asegurar un sostén correcto a la base, a la punta y al dorso nasal; darle al paciente un aspecto estéticamente mejor, también para solucionar problemáticas psico-sociales concomitantes; y restablecer una oclusión correcta. No hay acuerdo entre los diferentes autores sobre el período más oportuno en que iniciar la terapia quirúrgica de la nariz. Autores como Ortiz Monasterio, ${ }^{17}$ proponen iniciar precozmente el tratamiento quirúrgico porque el niño tiene una ventaja psicológica gracias a la mejoría de su imagen corporal y porque se consigue un gradual aumento del sostén estructural y la progresiva expansión de los tejidos blandos en un período en el cual éstos son más elásticos. Sin embargo, hay autores como Posnick, ${ }^{18}$ que advierten sobre los posibles riesgos que tal cirugía precoz puede comportar, sobre todo el riesgo de formación de tejido cicatricial que hace más difícil las intervenciones siguientes y puede representar un obstáculo al crecimiento horizontal y vertical del maxilar superior. Para asegurar un sostén a la base de la nariz muchos autores han propuesto la utilización de injertos óseos o cartilaginosos:18,19 los injertos principalmente utilizados son los de cresta iliaca, de hueso craneal y de cartílago costal. Injertos óseos o cartilaginosos también son utilizados para la reconstrucción del dorso de la nariz: $\mathrm{Neu}^{20}$ aconseja el empleo de hueso craneal para la reconstrucción de los $2 / 3$ superiores del dorso nasal, mientras el cartílago del tabique nasal o el cartílago auricular para el $1 / 3$ inferior y la punta. De este modo la punta de la nariz no posee la rigidez que se tiene cuando se reconstruye dorso, punta y columela solo con un injerto óseo modelado en "L." Nosotros creemos que la intervención de rinoplastia debe ser efectuada tras el crecimiento completado, después de la intervención de cirugía ortognática. El injerto cartilagi- with abnormalities of the nasal septum, which appears less developed and with less calcification than normal. A vitamin K-dependant protein has been found within the cartilage, matrix GLA protein. Although the exact function of this protein is not known, its presence in growth cartilage suggests that its normal function is to prevent calcification. In fetuses with vitamin $K$ deficiency, the matrix GLA protein should be present in an inactive form and therefore it would not be able to prevent uncontrolled calcification. In Binder syndrome, ectopic calcification of the suture between the vomer and premaxilla, between the sixth and twelfth week of embryonic life, could be responsible for maxillonasal hypoplasia. However, Howe's hypothesis 12,13 is not applicable to all individuals with Binder syndrome, as not all have experienced a prenatal deficit of Vitamin K, but it does helps to clarify the etiopathogenesis of Binder syndrome, which is still very confusing. Various theories as to its pathogenesis have been put forward by many authors. Binder ${ }^{1}$ believed that the syndrome with his name derived from a failed induction attempt of the prosencephalon on the growth of the premaxilla. Resche et al. ${ }^{14}$ suggested that the pathogenic noxa responsible for Binder syndrome had to act at the same time as the cervical vertebrae were developing, as the malformation of the latter were present in more than $50 \%$ of Binder syndrome cases. Converse et al. ${ }^{15}$ believed that the reduction in the growth of the premaxilla was due to disturbance to the cartilaginous structure, while Noyes 2 believed that the syndrome was caused by trauma during birth. While its etiopathogenesis is greatly debated, together with the definition of Binder syndrome itself, there is even less consensus in the literature with regard to therapy. This is probably due to the rarity of the syndrome that does not permit carrying out studies with a sufficient number of cases, and which does not permit treatment comparisons based on solid statistics. It is obvious that Binder patients should be treated specifically according to their age and the seriousness of the pathology. We may in fact come across patients with an Angle Class III molar relationship and a moderately flattened nose, and we may also find individuals with advanced Class III, with an anterior open bite, a nasofrontal angle of $180^{\circ}$, with associated cervico-spinal pathologies and mental retardation. Orthodontia plays a primary role in the milder cases, as well as in the more serious cases. In the former cases orthodontic therapy may be sufficient for reestablishing an acceptable aesthetic appearance together with acceptable stomatognathic function. The objectives of orthodontia are to:

1)Antagonize or correct the contraction of the upper jaw; 2) achieve occlusal adjustment; 3) stimulate the sagittal development of the maxillary bone (Delaire mask); 4) prepare the patient for orthognathic surgery when this is necessary.

Following a radiological study on an 11 year old boy, Rune et al. ${ }^{16}$ maintained that the Delaire mask was less effective in advancing the maxilla in Binder patients compared to those patients without the syndrome. According to the authors, this was as a result of the reduced growth capacity of the circum-maxillary sutures. In addition, when the Delaire mask was removed, there was near complete relapse. 
noso costal utilizado para dar sostén a la base nasal y para reconstruir, a través de injerto modelado en "L", la punta y el dorso nasal, nos ha permitido conseguir óptimos resultados estético-funcionales, con buena estabilidad en ausencia de rigidez de la punta nasal. Además, por lo que concierne a la corrección de la alteración occlusal, la intervención de cirugía ortognática más utilizada es la osteotomía de Le Fort I, asociada o menos a osteotomia sagital bilateral de la mandíbula y/o a disyunción mediana del maxilar superior para conseguir su expansión. Tal intervención es, según nuestra escuela, ejecutada al final del crecimiento (15-16 años). Posnick, ${ }^{18}$ ha demonstrado que después de una osteotomía de Le Fort I con fijación rígida interna en 7 pacientes afectos por $\mathrm{S}$. de Binder la recidiva maxilar es mínima en la dimensión vertical, mientras casi es inexistente para la dimensión horizontal. También en nuestra experiencia, después de un seguimiento de cuatro años, los medios de fijación rígida interna utilizada garantizan total estabilidad esquelética.

\section{Conclusiones}

El diagnóstico del síndrome de Binder es clínico y radiológico. Clínicamente, la hipoplasia premaxilar junto a clase III dentoesquelética y la deformidad de la pirámide nasal son las características distintivas; radiológicamente, la ausencia de la espina nasal anterior es la imagen patognomónica para el diagnóstico de este síndrome. El tratamiento de las formas más graves no puede que ser quirúrgico y tiene que basarse en la intervención de cirugía ortognática, que debe ser ejecutada al final del crecimiento después de un adecuado tratamiento ortodóntico pre-quirúrgico, seguido mediante una intervención de rinoplastia. Esta última tiene que prever el injerto de tejido autólogo para reconstruir el dorso, la punta nasal y dar sostén a la base de la nariz. El cartílago costal se ha mostrado en nuestra experiencia ideal gracias a la posibilidad de garantizar un sostén adecuado, manteniendo la natural movilidad de las estructuras de la porción inferior del dorso nasal, de la punta y de la columela.

\section{Bibliografía}

1. Binder KH. Disostosis maxillo-nasalis, ein arhinencephaler Missbildungscomplex. Dtsch. Zahnaerztlz 1962;17:438.

2. Noyes FB. Case report. Angle Orthod 1939;9:160.

3. Zuckerkandl E. Fossae prenasales. Normale und pathologische. Anat Nasenhohle 1882;1:48.

4. Holmstrom H. Clinical and pathologic features maxillonasal dysplasia (Binder's Syndrome): significance of the prenasal fossa on etiology. Plast Recontr Surg 1986;78:559-67.

5. Mulhern DM. Probable case of Binder Syndrome in a skeleton from Quarai, New Mexico. Am J Phys Anthropol 2002;118:371-7.

6. Delaire J, Billet J, Lediascorn H. Le Syndrome de Binder (quatre observations). Rev Stomatologi 1970;1:257-60.

7. Olow Nordenram MAK, Radberg CT. Maxillonasal dysplasia (Binder Syndrome) and associated malformations of the cervical spine. Acta Radiologica 1984;25:35360.
The more serious cases require surgical therapy. The objectives of surgery are: to ensure the base of the nose is correctly fixed to the tip and dorsum; to improve the patient's aesthetic appearance; to solve any accompanying psychosocial problems; to re-establish correct occlusion.

There is no consensus among the different authors as to the most appropriate period for starting surgical treatment of the nose. Authors such as Ortiz Monasterio ${ }^{17}$ propose starting surgical treatment promptly because the child will have a psychological advantage as his body image will improve, and because there will be a gradual increase in structural support together with progressive soft tissue expansion at a time when these are more elastic. However, authors such as Posnick ${ }^{18}$ warn of the possible risks of this type of early surgery, especially the risk of scar tissue formation that make further interventions more difficult, and which may represent an obstacle to the horizontal and vertical growth of the upper jaw.

To ensure proper support for the nasal base, many authors have proposed using bone or cartilage grafts. ${ }^{18,19}$ The main grafts used are iliac crest, cranial bone and rib cartilage. Bone or cartilage grafts are also used for the reconstruction of the nasal dorsum. Neu20 recommends the use of cranial bone for the reconstruction of the upper two thirds of the nasal dorsum, and cartilage from the nasal septum, or auricular cartilage for the lower third and tip. The tip of the nose will not therefore have the rigidity of a reconstruction carried out of the dorsum, tip and columella with a single L-shaped bone graft. We believe that rhinoplasty surgery should be carried out once growth is complete and after orthognathic surgery. The rib cartilage graft used for providing support for the nasal base and for reconstructing the nasal tip and dorsum, once shaped into an L, has allowed us to achieve optimum aesthetic-functional results, with good stability and with no rigidity of the nasal tip. In addition, with regard to the correction of occlusal alteration, the orthognathic surgical procedure most used is the Le Fort I osteoto$m y$, in conjunction with a bilateral sagittal osteotomy of the mandible and/or median disjunction of the upper jaw in order to achieve expansion. This intervention, according to our school, should be carried out at the end of the growth period (15-16 years). Posnick ${ }^{18}$ demonstrated with seven Binder syndrome patients who underwent Le Fort I osteotomies with rigid internal fixation, that relapse in the vertical dimension was minimal in the maxilla, while in the horizontal dimension relapse was practically nil. In addition, our experience with a follow-up of four years, shows that internal rigid fixation guarantees total skeletal stability.

\section{Conclusions}

The diagnosis of Binder syndrome is through clinical and radiological examination. Clinically, premaxillary hypoplasia together with class III dentoskeletal features and deformity of the nasal pyramid are the distinctive characteristics. 
8. Jackson IT, Moos KF, Sharpe DT. Total surgical management of Binder's Syndrome. Ann Plast Surg 1981;7:25-31.

9. Horswell BB, Holmes AD, Levant BA, Barnett JS. Cephalometric and anthropometric observations of Binder's Syndrome: a study of 19 patients. Plast Recostr Surg 1988;81:325-35.

10. Horswell BB, Holmes AD, Barnett JS, Levant BA. Maxillonasal dysplasia (Binder Syndrome): A critical study and case study. J Oral Maxillofac Surg 1987;45:11422.

11. Sheffield LJ, Danks DM, Mayne V. Chondrodysplasia punctata: 23 cases of a nild and relatively common variety. J Pediatrics 1976;89:916-21.

12. Howe H. Binder's Syndrome due to prenatal vit K deficiency: a theory of pathogenesis. Aust Dent J 1992;37:453-60.

13. Howe H. Prenatal exposure to phenintoin, facial development, and a possible role for vitamin K. Am J Med Gen 1995;58:238-44.

14. Reche F, Tessier P, Delaire J. Craniospinal and cervicospinal malformations. Head Neck Surg 1980;3:123-31.

15. Converse JM, Horowitz SL, Valauri AJ. Pyramidal naso-orbital maxillary osteotomy. Plast Recostr Surg 1970;45:527-32.

16. Rune B, Sarnas KV, Selvik G, Jacobsson S. Posteroaterior traction in maxillonasal dysplasia (Binder syndrome). A roentgen stereometric study with the aid of metallic implants. Am J Orthod 1982;81:65-69.

17. Ortiz Monasterio F. Nasal correction in Binder's syndrome: the evolutio of a treatment plan. Aesth Plast Surg 1997;21:299-308.

18. Posnick JC, Tompson B. Binder Syndrome: staging of reconstruction and skeletal stability and relapse patterns after LeFort I osteotomy using miniplate fixation. Plast Reconstr Surg 1997;99:961-73.

19. Rune B, Aberg M. Bone graft to the nose in Binder's Syndrome (maxillonasal dysplasia): a follow-up of eleven patients with the use of profile roentgenograms. Plast Reconstr Surg 1998;101:297-304.

20. Neu B. Segmental bone and cartilage reconstruction of major nasal dorsal defects. Plast Reconstr Surg 2000;106:160-70.
Radiologically, the absence of the anterior nasal spine is the pathognomonic feature for diagnosing this syndrome. The therapy for more serious forms should therefore be surgical and based on orthognathic surgery, which should be carried out at the end of the growth period after adequate orthodontic pre-surgical treatment, and this should be followed by rhinoplasty surgery. This should envisage an autologous tissue graft for reconstructing the nasal dorsum and tip, and for supporting the nasal base. In our experience, rib cartilage has shown itself to be ideal, given the possibility of guaranteeing adequate support while maintaining the natural movement of the structures in the lower portion of the nasal dorsum, tip and columella. 